\title{
The CRC comes of age: assessing progress in meeting the rights of children in custody in Northern Ireland
}

\author{
DR LINDA MOORE ${ }^{1}$
}

School of Criminology, Politics and Social Policy, University of Ulster

\begin{abstract}
$\underline{\text { Abstract }}$
This article focuses on the extent to which Convention rights are complied with regarding the treatment of children in conflict with the law in Northern Ireland, and in particular the rights of incarcerated children. Relevant children's rights instruments and principles are identified to establish the benchmarks for this discussion. There follows discussion of the particular social, economic and political context which impacts upon the lives of children in conflict with the law in Northern Ireland. The legislative context for the detention of children in custody in Northern Ireland is explored, and the regimes in the Juvenile Justice Centre (JJC) for Northern Ireland and Hydebank. Wood Young Offenders Centre (YOC) are assessed for compliance with children's rights standards. Primary research conducted by the author and her colleagues with children in custody in Northern Ireland ${ }^{2}$ and recent inspection and research reports form the basis for the analysis of the state of children's rights in custody in Northern Ireland in the 21st century.
\end{abstract}

\section{Introduction}

7 he 21 st "birthday" of the United Nations Convention on the Rights of the Child (CRC) 1989 provides an opportunity to reflect on what has been achieved through the Convention and to identify deficits and challenges ahead. The focus of this article is on the extent to which Convention rights are complied with regarding the treatment of children in conflict with the law in Northern Ireland, in particular the rights of incarcerated children. The article begins by identifying relevant international children's rights standards and then moves to a discussion of the social, economic and political context within which the lives of children in conflict with the law are situated. There follows an assessment of the extent to which children's rights are respected in the youth justice system in Northern Ireland, especially the rights of children in custody. The findings from primary research by the author with children and staff in the JJC for Northern Ireland (conducted with her colleague Dr Una Convery and published by the Northern Ireland Human Rights

1 Linda Moore is also policy consultant to the Children's Law Centre. She was previously investigations worker for the NIHRC. All views expressed in this article are the author's own and are not attributable to any organisation.

2 See the following reports researched for the NIHRC and co-authored with Dr Ursula Kilkelly and Dr Una Convery: U Kilkelly, L Moore and U Convery, In Our Care: Promoting the rights of children in custody (Belfast: NIHRC 2002); U Convery and L Moore, Still in Our Care: Protecting children's rights in custody in Northern Ireland (Belfast: NIHRC 2006). 
Commission (NIHRC)) are included within this analysis to bring to the fore the voices of children in custody and the staff who work with them. ${ }^{3}$

\section{The CRC and the criminal justice system}

The CRC establishes rights for all children under 18 years of age $e^{4}$ and includes special protections for children in conflict with the law. States which have ratified the CRC are required to report to the United Nations Committee on the Rights of the Child (the Committee) every five years, and the Committee responds through the publication of observations which may be used by non-governmental organisations and campaigning groups as a lobbying tool and to embarrass states which contravene the Convention. The CRC is legally binding under international law but has not been incorporated into domestic law in the UK meaning that the rights therein are not legally enforceable in domestic courts. Courts may, however, use the Convention in interpreting rights contained within the European Convention on Human Rights (ECHR), introduced into domestic law as the Human Rights Act (1998). Kilkelly observes that "although the ECHR is short on substantial rights for children, a number of its features make the use of the CRC as an interpretive guide both possible and valuable". 5

Core Convention principles which must underpin children's treatment by the criminal justice system include the right to be free from discrimination, ${ }^{6}$ the primacy of the best interests of the child, ${ }^{7}$ the right of the child to be listened to and to participate in decisions affecting him or her, ${ }^{8}$ and the right to be protected. ${ }^{9}$ Children must not be detained unlawfully or arbitrarily and their detention or imprisonment must be used "only as a measure of last resort" and "for the shortest appropriate period of time". 10 Thomas Hammarberg, Council of Europe Commissioner for Human Rights, maintains that the judicial body should represent the "last link in the chain" and everything possible should be done to prevent cases involving children coming into the formal justice process. ${ }^{11}$ Article 37C CRC confirms the right of detained children to be treated with "humanity" and "dignity" and forbids the detention of children with adults except in exceptional situations where this is in the child's best interests. Detained children have the right to prompt legal advice and to challenge their detention through the courts. ${ }^{12}$ Article 40 requires that the legal process should take account of children's age and the importance of reintegrating into society children who offend; children have a right to a presumption of innocence, to have their case processed without delay, to remain silent without prejudice and to have their privacy respected. Article 40 also requires the establishment of a minimum legal age of criminal responsibility, diversion of children from the justice system where appropriate and provision of a broad range of diversionary measures to avoid so far as possible the

3 Convery and Moore, Still in Our Care, n. 2 above.

4 Article 1 CRC.

5 U Kilkelly, “The best of both worlds for children's rights? Interpreting the European Convention on Human Rights in the light of the UN Convention on the Rights of the Child" (2001) 23(2) Human Rights Quarterly 308-26, p. 313.

6 Article 2 CRC.

7 Article 3 CRC.

8 Article 12 CRC.

9 Article 19 CRC.

10 Article 37 CRC.

$11 \mathrm{~T}$ Hammarberg, Viewpoint: It is wrong to punish child victims, 8 January 2007, available at www.coe.int/t/commissioner/Viewpoints/070108_en.asp.

12 Article 37D CRC. 
placement of children in institutions. In its judgment in the cases of $T_{\mathrm{v}} U K$ and $V_{\mathrm{v}} U K,{ }^{13}$ regarding the trial in an adult court of two boys convicted at age 11 of the murder of twoyear-old James Bulger and sentenced to detention during Her Majesty's Pleasure, the European Court found that the boys' right to a fair trial (Article 6 EHCR) had been violated as the children had been "unable to participate effectively in the criminal proceedings". ${ }^{4}$ The judgment made reference to the CRC, the observations of the Committee on the Rights of the Child and the United Nations Standard Minimum Rules for the Administration of Juvenile Justice 1985 (the Beijing Rules). Kilkelly observes that the case provided "firm evidence that the CRC's standards in the area of juvenile justice have been accepted by the Court". 15

Alongside the UN Convention, other international instruments for youth justice include the Beijing Rules; the United Nations Guidelines for the Prevention of Juvenile Delinquency 1990 (the Riyadh Guidelines); the United Nations Rules for the Protection of Juveniles Deprived of their Liberty 1990 (the Havana Rules); and the United Nations Standard Minimum Rules for Non-custodial Measures 1990 (the Tokyo Rules). Taken together these instruments provide the basis for a youth justice system based on prevention of offending through support for children, their families and communities; respect for children's privacy; diversion from and alternatives to prosecution; restorative measures; minimal use of detention; and the rehabilitation and (re)integration of children into society. Although no specific age is given for the minimum age of criminal responsibility, the Beijing Rules advise that the age should be broadly consistent with other rights and responsibilities, such as the age of marriage or civil majority. ${ }^{16}$

The Committee on the Rights of the Child in its General Comment on Children's Rights and Youth Justice ${ }^{17}$ notes that in all matters regarding youth justice the best-interest principle must be a primary consideration and at all stages of the justice process children's voices must be heard and respected. In effect, this means that "the traditional objectives of repression/retribution, must give way to rehabilitation and restorative justice objectives in dealing with child offenders". ${ }^{18}$ Depriving children of their liberty in general has "very negative consequences for the child's harmonious development and seriously hampers his/her reintegration in society". ${ }^{19}$ The Committee comments that setting the minimum age of criminal responsibility below 12 years of age is unacceptable and a higher age, between 14 and 16 years, encourages greater use of diversionary and restorative measures and provides greater protection of children's rights. ${ }^{20}$ The Committee is critical of lengthy custodial remands which are considered a "grave violation" of the Convention. ${ }^{21}$ Children must not be placed in adult prisons as this "compromises their basic safety, well-being, and their future ability to remain free of crime and to reintegrate". 22 Facilities for children should include "distinct, child-centred staff, personnel, policies and practices". ${ }^{23}$ Children

13 T v United Kingdom (16 December 1999), App. No. 24724/94 and V v United Kingdom (16 December 1999), App. No. 24888/94.

$14 \quad V \mathrm{v} U K(1999) \mathrm{C}(89)$.

15 Kilkelly, "The best of both worlds", n. 5 above, p. 324.

16 Rule 4.1.

17 CRC, General Comment No. 10: Children's Rights in Juvenile Justice, CRC/C/GC/10, 25 April 2007.

18 Ibid. para. 12.

19 Ibid. para. 11.

20 Ibid. paras 32 and 33.

21 Ibid. para. 80.

22 Ibid. para. 85.

23 Ibid. 
should be able to stay beyond their 18th birthday in the children's facility, providing it is in their best interests and not contrary to younger children's interests. ${ }^{24}$ Those in authority are required to be well trained and to provide positive role models for children. ${ }^{25}$

In its concluding observations on the United Kingdom in 2008, 26 the Committee on the Rights of the Child welcomed the government's announcement that the reservation to Article 37C, which specified that children should not be held in custody with adults, was to be withdrawn. ${ }^{27}$ The Committee also welcomed the intention to introduce a Bill of Rights (BOR) in Northern Ireland and recommended that a specific section of the Bill be dedicated to children's rights. ${ }^{28}$ It commented on the deaths of six children in custody in England and Wales since the previous examination in 2002 and on the high levels of selfharm among children in custody. ${ }^{29}$ Punitive and stigmatising approaches were criticised as breaching children's rights including anti-social behaviour orders, negative and intrusive media coverage of children, and routine retention of children's DNA. ${ }^{30}$ Concern was expressed at the continued use of physical restraint in institutions where children were deprived of their liberty and the Committee stated that restraint should be used only as a last resort and only to protect the child or others from harm. ${ }^{31}$ The Committee was critical of the inadequate provision of dedicated mental health services for children and referred to the particular problems for children in Northern Ireland due to the legacy of the conflict. ${ }^{32}$

With regard to youth justice, the Committee once again criticised the low age of criminal responsibility and expressed concern about the high numbers of children in custody, the levels of custodial remand, the absence of a statutory right to education for children in custody and the continued practice of detaining children alongside adults. ${ }^{33}$ The Committee recommended full compliance with Convention rights on youth justice as well as compliance with other international instruments, raising the age of criminal responsibility and the development of appropriate alternative measures to avoid the criminalisation of children or deprivation of their liberty. ${ }^{34}$

At the time of writing, the Council of Europe is in the process of finalising new guidelines on child-friendly justice. ${ }^{35}$ The draft guidelines were produced following widespread consultation, including with children and young people. Over 3700 responses were analysed by Irish children's rights expert, Dr Ursula Kilkelly. Child-friendly justice is defined as:

justice that is accessible, age appropriate, speedy, adapted to and focused on the needs of the child, respecting the rights of the child including the rights to due

24 CRC, General Comment No. 10, para. 86.

25 Ibid. para. 13.

26 CRC, 49th Session, Consideration of Reports submitted by States Parties under Article 44 of the Convention: Concluding Observations on the United Kingdom of Great Britain and Northern Ireland, $\mathrm{CRC} / \mathrm{C} / \mathrm{GBR} / / \mathrm{CO} / 4,3$ October 2008. Ibid. para. 8 .

28 Ibid. para. 11.

29 Ibid. para. 29.

30 Ibid. paras 35 and 36.

31 Ibid. paras 38 and 39.

32 Ibid. paras 56 and 57.

33 Ibid. para. 77.

34 Ibid. para. 78.

35 Council of Europe, Group of Specialists on Child-friendly Justice, Final Draft Recommendation Containing Guidelines of the Committee of Ministers of the Council of Europe on Child-friendly Justice (Strasbourg: Council of Europe 2010). 
process, to participate in and understand proceedings, to privacy and to integrity and dignity. ${ }^{36}$ The provisions in the guidelines are built upon the principles contained in the other international instruments. With regard to custody, the guidelines state that "in all circumstances, children shall be detained in premises suited to their needs". 37

A recent European Court decision has given added strength to the principle that children should not be detained in adult institutions. In Güvec v Turkey, ${ }^{38}$ the applicant, Oktay Güveç, alleged that his detention for five years along with adults and his trial at 15 years of age before the State Security Court, rather than a juvenile court, was in breach of his rights under Article 3 of the ECHR. During his imprisonment the applicant had been depressed and suicidal and had set fire to himself, suffering serious burns, but did not receive appropriate medical attention, including effective mental health care. Doctors confirmed that the conditions of imprisonment seriously exacerbated the applicant's mental health problems. The court concluded that:

having regard to the applicant's age, the length of his detention in prison together with adults, the failure of the authorities to provide adequate medical care for his psychological problems, and, finally, the failure to take steps with a view to preventing his repeated attempts to commit suicide, the Court entertains no doubts that the applicant was subjected to inhuman and degrading treatment. ${ }^{39}$

\section{Context of poverty, social exclusion and conflict in Northern Ireland}

Thomas Hammarberg reminds us that a child in conflict with the law "is sometimes a victim as much as an offender. The social background is often tragic." 40 Developments in criminal justice in Northern Ireland can best be understood within the context of a society emerging from violent conflict. Between 1966 and 2003, over 3700 people lost their lives and more than 40,000 were seriously wounded as a result of the "Troubles". 41 Thirty-six per cent of those killed in the conflict were children and young people. ${ }^{42}$ Marie Smyth and colleagues report that, of those killed, 274 were children under 18 and 629 were aged 18 to 21.43 Children in Northern Ireland have been subject to, and witnesses of, many forms of violence carried out by state and non-state groups and individuals including paramilitary punishment attacks, bombings, shootings, sectarian violence and bullying, house-raids, and exile and forced removal from home. Geographically and socially the impact has not been evenly experienced; six Northern Ireland postal areas accounted for 58 per cent of conflictrelated deaths of children. ${ }^{44}$

A study scoping children's rights in Northern Ireland published by the Northern Ireland Commissioner for Children and Young People (NICCY) found that children living in highconflict or interface areas raised issues of "rioting, punishment attacks by paramilitaries,

36 Council of Europe, Final Draft Recommendation, n. 35 above, para. $1 \mathrm{~b}$.

37 Ibid. para. 6.2

38 Güveçv Turkey, App. No. 70337/01, Council of Europe, European Court of Human Rights, 20 January 2009.

39 Ibid. para. 98.

40 T Hammarberg, "A juvenile justice approach based on human rights principles" (2008) 8(3) Youth Justice 193-6, p. 195.

41 A Edwards and C McGrattan, The Northern Ireland Conflict (Oxford: One World publications 2010), p. xviii.

42 Office of the First Minister and Deputy First Minister (OFM/DFM), Our Children and Young People: Our pledge. A ten year strategy for children and young people in Northern Ireland 2006-2016 (Belfast: OFM/DFM 2006), p. 30.

43 M Smyth, with MT Fay, E Brough and J Hamilton, The Impact of Political Conflict on Children in Northern Ireland (Belfast: Institute for Conflict Research 2004), pp. 18-20.

44 M Smyth, Half the Battle: Understanding the impact of the troubles/conflict on children and young people in Northern Ireland (Derry/Londonderry: INCORE 1998), para. 3.2.2. 
negative attitudes to the police, joy riding, the availability of alcohol and drugs, and the lack of amenities and safe social spaces". Community workers in these areas urged a "reconsideration of how children in conflict with the law are defined and criminalised" and identified a failure to recognise "the generational hand-down of trauma". 45 The government-commissioned Bamford Review of Mental Health and Learning Disability found "major deficits" in child and adolescent mental health services in Northern Ireland and noted the "high price" that society paid for this in terms of "social disruption, education failure, ill health, anti-social behaviour, and hard cash". ${ }^{46}$

Recent research demonstrates that although levels of violence are significantly reduced in Northern Ireland since the paramilitary ceasefires of 1994 and the subsequent Belfast/Good Friday Agreement, violence and conflict have not disappeared and the transition process to peace is difficult and uneven. Goretti Horgan and Marina Monteith found that: "Northern Ireland's most disadvantaged children and young people live in communities which face social exclusion and still experience violence that is the legacy of the conflict." They note "growing evidence that high levels of mental ill-health are significantly related to the conflict, including the psychological distress suffered by those who appeared resilient during the conflict". ${ }^{47}$ Despite the evidence that today's children and young people are affected by intergenerational trauma, government concedes that the "quality, consistency and accessibility" of child and adolescent mental health services is inadequate. ${ }^{48}$

McAlister et al.'s recent study of children's lives in six communities in Northern Ireland, based on qualitative research with over 200 children and young people aged 8 to 25 and the adults who work with them, highlighted the negative media constructs of children and young people and their concerns that being labelled as "hoods" and trouble-makers could bring them to the attention of the authorities and result in criminalisation. ${ }^{49}$ The study found that the conflict was far from over for many young people who still experienced sectarian threats and violence and were under pressure from paramilitary groups and distrustful of the police. The continued impact of conflict-related trauma was a common theme raised by interviewees:

There are hundreds of families here and in other communities who are voiceless - the voiceless of the Conflict - they don't get involved or speak out publicly. There are huge amounts of pain there and they are highly traumatised. The children of the conflict have seen their parents medicated with tranquillisers they never told their story or had their pain recognised. ${ }^{50}$

McAlister et al. conclude that:

many community representatives and young people expressed frustration that the Peace Agreements had not brought significant change. The impact and legacy of the Conflict had been ignored and communities left without necessary economic and social support. 51

45 U Kilkelly, R Kilpatrick, L Lundy, L Moore, P Scraton, C Davey, C Dwyer and S McAlister, Children's Rights in Northern Ireland (Belfast: NICCY 2004), p. xvii.

$46 \mathrm{R}$ McClelland, The Bamford Review of Mental Health and Learning Disability: A vision of a comprehensive child and adolescent mental bealth service (July 2006). Foreword and Annex 1: 1.4.

47 G Horgan and M Monteith, What Can We Do to Tackle Child Poverty in Northern Ireland? (York: Joseph Rowntree Foundation 2009), p. 1.

48 OFM/DFM, Our Children and Young People, n. 42 above, p. 30.

49 S McAlister, P Scraton and D Haydon, Childhood in Transition: Children and young people experiencing marginalisation in Northern Ireland (Belfast: Queen's University/Save the Children/Prince's Trust 2009).

50 Community worker interviewed in ibid. p. 50.

51 Ibid. p. 81. 
Concerns were expressed about young people's heavy use of alcohol, and "street fighting" which impacted on their safety and that of others. ${ }^{52}$ The police were on the whole viewed as "unwilling, unable or ill-equipped" to deal with the problems posed by young people's offending behaviour. ${ }^{53}$

\section{Protecting the rights of children in custody in Northern Ireland}

An assessment of the extent to which CRC rights have been achieved for children in custody in Northern Ireland, must take place within the context of other legal, political and social developments in the jurisdiction. These include the introduction of the Human Rights Act (1998), the signing of the Belfast/Good Friday Agreement (1998), ${ }^{54}$ the subsequent review of the criminal justice system, consultation on a BOR for Northern Ireland and the more recent Hillsborough Agreement (2010) which established the devolution of criminal justice. The Belfast/Good Friday Agreement recognised that "young people from areas affected by the troubles face particular difficulties" creating a need for "special community-based initiatives based on international best practice". 55 Recognising the importance of a human rights and equality-based justice system, the Agreement established a range of bodies designed to enhance rights within the justice system. These included independent reviews of policing ${ }^{56}$ and the criminal justice system, ${ }^{57}$ as well as the creation of independent accountability or "watchdog" bodies such as the Police Ombudsman, Prisoner Ombudsman, Criminal Justice Inspection for Northern Ireland (CJINI), NIHRC and the NICCY.

The Criminal Justice (Children) (Northern Ireland) Order 1998 provides the legislative basis for the use of custody for children in this jurisdiction. The order created a separate youth justice system based on determinate sentencing, ending the historical practice of housing children detained for child welfare reasons in the same institutions as those remanded or sentenced for criminal offences. The order aimed to tackle the problem of children languishing for months, and even years, on remand and on indeterminate sentences and, to this end, it restricted the circumstances in which children could be remanded to custody and placed a requirement on the court to give reasons for the use of custody. The CJINI describes the order as being based on international best practice and on human rights standards, ${ }^{58}$ however, the legislation contains breaches of rights in important respects. The requirement in the order that the court must take into account the welfare of the child ${ }^{59}$ falls short of the best-interests principle required by CRC Article 3. Contrary to the recommendations of the Committee on the Rights of the Child, the order retains the age of criminal responsibility at 10 years, removing the rebuttal principle of doli incapax, the assumption that a child under 10 is incapable of committing an offence unless otherwise established for the court. ${ }^{60}$ It provides for a determinate custodial disposal, the juvenile

52 McAlister et al., Childhood in Transition, n. 49 above, p. 83.

53 Ibid. p. 74.

54 Agreement Reached in the Multi-Party Negotiations, 10 April 1998 (hereinafter Belfast/Good Friday Agreement). The Belfast/Good Friday Agreement was a multi-party agreement which led to the establishment of devolved power-sharing government for Northern Ireland.

55 Belfast/Good Friday Agreement, para. 6.12.

56 Independent Commission on Policing in Northern Ireland (the Patten Commission) which produced its report in September 1999: A New Beginning: Policing in Northern Ireland (Belfast: Northern Ireland Office 1999).

57 The Criminal Justice Review reported in 2000: Criminal Justice Review Group, Review of the Criminal Justice System in Northern Ireland (Belfast: HMSO 2000).

58 CJINI, Inspection of Woodlands Juvenile Justice Centre (Belfast: CJINI 2008), para. 1.2.

59 Ibid. Part 2, s. 4a.

60 Ibid. Part 2, s. 3. 
justice order (JJO) which may be between six months and two years, half of which are spent in custody and half under Probation Service supervision in the community. "Seriousness" and "persistence" of offending are the basis for the use of JJOs, the latter criteria arguably breaching Article 37B which requires that the use of detention should be a last resort and for the "shortest appropriate period of time". The order retains the power of the court to sentence a child to a period of indeterminate custody at the Secretary of State's "pleasure" for grave crimes ${ }^{61}$ and to commit children aged 16 and over to prison service custody for defaulting on fines. ${ }^{62}$ Children aged 15 or over may be remanded to the prison-service-run YOC if they are considered a risk to themselves or others. ${ }^{63}$ The order initially failed to bring 17-year-olds within the youth court system but this was amended through the Justice (Northern Ireland) Act 2002 following the report of the Criminal Justice Review.

The Criminal Justice Review, established out of the Belfast/Good Friday Agreement (1998), did not initially have youth justice within its focus, but strong lobbying by a group of non-governmental organisations, brought together as the Criminal Justice (Children's) Lobby Group ${ }^{64}$ persuaded the review team that, as children's lives had been negatively impacted on by the conflict, so issues concerning children must be central to any future arrangements. In its report in 2000, the review recommended the closure of Lisnevin JJC (a prison-style institution which children's rights campaigners had been calling for the closure of for many years); the establishment of a Youth Justice Agency (YJA); the removal of children under the age of 14 from custodial institutions and their placement instead within the care system; the inclusion of 17-year-olds within the youth court system; a greater emphasis on the use of diversionary measures, reparation and restorative justice; and enhanced complaints and accountability mechanisms. Disappointingly for those concerned with children's rights, the review recommended that although 10 to 16 -year-olds should be held in JJCs (within the youth justice system), 17-year-olds should still be accommodated in prison service establishments. The review's recommendation that the age of criminal responsibility should be retained at 10 years of age was also a deep disappointment to the children's rights sector.

Recommendations from the Criminal Justice Review were enacted through the 2002 Justice (Northern Ireland) Act which was implemented in 2005. The Act established the principle aim of the youth justice system as the protection of the public by preventing offending by children. ${ }^{65}$ Schedule 11 brought 17 -year-olds within the jurisdiction of the youth courts ${ }^{66}$ and allowed for the detention of some within a JJC rather than in YOC prison service custody. However, the powers of the courts to give JJOs to 17-year-olds were restricted and only those children who will not reach their 18th birthdays during the period of the order and who have not received a custodial sentence in the previous two years may be considered. ${ }^{67}$ Other children serve their detention in Hydebank Wood YOC, which accommodates young adults and is a prison establishment. Two important changes were introduced in the Criminal Justice Order (Northern Ireland) 2008. In response to criticism of the conditions in which girls were held alongside adult women in Hydebank Wood by

61 CJINI, Inspection of Woodlands, n. 58 above, Part 6, s. 45(1)

62 Ibid.

63 Ibid. Part 6, s. 13(1)b.

64 Those participating in this group included representatives of Save the Children, Committee on the Administration of Justice, the Children's Law Centre (NI), Include Youth and the National Association of Probation Officers.

65 CJINI, Inspection of Woodlands, n. 58 above, Part 4, s. 53(1).

66 Ibid. Part 4, s. 63(1).

67 Ibid. Part 4, s. 64(3A). 
the NIHRC and the prisons and criminal justice inspectorates, ${ }^{68}$ Article 96 allowed for the court to accommodate 17-year-olds in the JJC where no "suitable" accommodation is available in a YOC. Article 97 removed the requirement that care orders be suspended where children are serving a JJO.

The Belfast/Good Friday Agreement tasked the newly created NIHRC with consulting on the content for a future BOR for Northern Ireland. ${ }^{69}$ In its advice presented to government in December 2008, the NIHRC recommended that rights which should be incorporated within a BOR include the right of children in conflict with the law "to be treated in a manner that pays due regard to the child's age, understanding, and needs and is directed towards the child's reintegration into society". The NIHRC also recommended that a future BOR should include clauses stating that children should not be detained except as a last resort and for the shortest appropriate period of time; that children must be held separate from adults; and must be subject to the use of force or restraint only to avoid serious injury to themselves or others. ${ }^{70}$ A clause was recommended requiring all public bodies to incorporate the "best-interests" and "participation" principles in all actions. ${ }^{71}$ The NIHRC recommended that government should consider increasing the minimum age of criminal responsibility to between 14 and 16 years, in line with the Committee on the Rights of the Child's recommendations, but that this should be accomplished through legislation and policy rather than being included within the BOR itself. ${ }^{72}$ Government's response to the NIHRC was to dismiss all but one of the proposed clauses relating to children's rights. ${ }^{73}$

A further development in 2010 was the devolution of criminal justice and policing matters to Northern Ireland's power-sharing government through the multi-party Hillsborough Agreement. ${ }^{74}$ The Hillsborough Agreement included provision for the Minister of Justice to establish, among other reviews, a review of prison conditions and oversight and a review of children's experiences in the criminal justice system. ${ }^{75}$

In 2010 in Northern Ireland, there are two custodial institutions used for the detention of children: the JJC for Northern Ireland and Hydebank Wood YOC. The JJC for Northern Ireland was established through a rationalisation of the juvenile justice estate in October 2003, close to Bangor town, about 10 miles from Belfast. The JJC comes under the authority of the YJA and accommodates up to 48 boys and girls, aged 10 to 17. The new JJC building known as Woodlands was opened in 2007 at a cost of $£, 16.8 \mathrm{~m}$. Woodlands is a secure establishment comprising six residential units, including one for girls, an

68 P Scraton and L Moore, The Prison Within: The imprisonment of women at Hydebank Wood: 2004-2006 (Belfast: NIHRC 2007); HM Chief Inspector of Prisons/CJINI, Report of an Unannounced Inspection of the Imprisonment of Women in Northern Ireland by HM Chief Inspector of Prisons and the Chief Inspector of Criminal Justice in Northern Ireland 28-30 November 2004 (Belfast: CJINI 2004).

69 The rights to be contained within a future Bill were to be supplementary to those contained within the ECHR and reflective of "the particular circumstances of Northern Ireland, drawing as appropriate on international instruments and experience". The Belfast/Good Friday Agreement also stated that the rights should reflect the "principles of mutual respect for the identity and ethos of both communities and parity of esteem".

70 NIHRC, A Bill of Rights for Northern Ireland (Belfast: NIHRC 2008), p. 25.

71 Ibid. p. 51.

72 Ibid. p. 135.

73 Northern Ireland Office, Consultation Paper: A Bill of Rights for Northern Ireland: next steps November 2009 (Belfast: NIO 2009), p. 62.

74 Agreement at Hillsborough Castle, 5 February 2010.

75 Hillsborough Agreement, para. 7. At the time of writing, the Prisons Review was being conducted by an independent review team headed by Dame Anne Owers, former Chief Inspector of Prisons for England and Wales. The Minister for Justice, David Ford, also announced the establishment of a review of the youth justice system in November 2010. Children's organisations expressed disappointment with the membership and terms of reference for this review. 
educational and vocational centre and a sports and leisure centre. The director, team leaders and unit managers are all social work-trained and there is an emphasis on staff training throughout the centre. ${ }^{76}$ Children may be remanded or sentenced to detention in the JJC through the provisions of the Criminal Justice (Children) (Northern Ireland) Order (1998) and also detained under the Police and Criminal Evidence (Northern Ireland) Order (1989) (PACE). All girls under 18 in custody in Northern Ireland are now held at Woodlands.

A thematic inspection by the CJINI in 2010 found that delay in the processing of children's cases remains a problem. ${ }^{77}$ The Children and Young People's Strategy found that the average time taken to process a child from the date of summons until the date of disposal was 20.7 weeks and established as a target that delays should be reduced. ${ }^{78} \mathrm{~A}$ commitment was expressed for all agencies involved in criminal justice to work to reduce the likelihood of offending by children and young people and it was noted that a "wider range of community alternatives" had been provided to the courts to reduce the need for custodial disposals. Targets regarding youth justice included a reduction in the number of children entering the youth justice system; a reduction in children's offending; and fewer children sentenced to custody. ${ }^{79}$

The primary research on the protection of the rights of children in the JJC for Northern Ireland conducted by the author, with her colleague Dr Una Convery for the NIHRC identified both positive developments and also continued breaches of children's rights. ${ }^{80}$ The report Still in Our Care was based on primary research with managers, care staff and other professionals, and children at the JJC for Northern Ireland in 2005. As evidenced by recent inspection reports and research conducted by non-governmental organisations (discussed below) the issues highlighted here remain pertinent. Interviews were important in recording the views and experiences of children and bringing the voices of children to the fore. Formal interviews were conducted with 11 boys and one girl (just under half of the children living in the centre at the time of fieldwork) and with 13 care staff members. The research was carried out over 10 days, which was the extent of access granted, and had to be undertaken during times when children were not at school or involved in activities. ${ }^{81}$ Given the busy daily routine at the centre, this limited the number of interviews which could be conducted with children. The researchers were also given the opportunity to talk informally with staff and children and observe daily life in the centre. They joined staff and children for lunch in the units, visited the education unit during school hours, and also attended a management meeting. Although these conversations were treated as confidential, they provided further insight into the operation of and atmosphere in the centre. All quotations below unless otherwise referenced are taken from the primary research interviews. The research aimed to take stock of the implementation of previously made recommendations 82 and hoped to inform plans for a new "state of the art facility" which was being developed at that time to replace the existing building on the same site (opened in 2007 as Woodlands JJC).

76 CJINI, Inspection of Woodlands, n. 58 above, p. 11.

77 CJINI, Avoidable Delay: A thematic inspection of avoidable delay in the processing of criminal cases in Northern Ireland (Belfast: CJINI 2010).

78 OFM/DFM, Our Children and Young People, n. 42 above, p. 63

79 OFM/DFM, Our Children and Young People: Our pledge: action plan 2008-2011 (Belfast: OFM/DFM 2008), p. 68.

80 Convery and Moore, Still in Our Care, n. 2 above.

81 Access was initially denied to the Commission by the NIO and was granted only after judicial review proceedings were initiated.

82 Kilkelly et al., In Our Care, n. 2 above. 
The primary research demonstrated that, contrary to the requirements of CRC Article 37, custodial sentences and remands are not used only as a last resort or for the shortest appropriate time. Care staff raised the issue of the detention of children for relatively minor offences being held alongside children detained for serious offences:

You could have a boy in because he's broke windows and you could have a boy in because he's attempted murder, and that's a fault . . . You've also got boys in here with maybe 100 car crimes and they're mixing with the window breaker, maybe selling drugs and that.

Staff considered that children were being held for longer than necessary on remand because there was insufficient capacity for bail placements:

If the courts can give bail after two weeks or one month they should be able to give it after two days, instead young people are in for months . . . some are remanded as long as ones are sentenced.

The need for more community-based provision was reinforced by staff:

I had concerns around a vulnerable child, a "care child" in the unit with [a young person] who is highly dangerous with serious psychological problems and emotional issues ... We need more fostering placements.

Children's views supported those of staff: "The judge just had me remanded because they can't get me a place." A further explanation given by staff and children for the overuse of custody was the failure of solicitors and/or social workers to attend court hearings:

I was remanded because there was no-one there to represent me ... My solicitor's ... never there ... The day I was put in here, he spoke to me for about five minutes and told me that whenever I went up to the court that he would see me. I went up . . . and there was someone there representing me that I didn't even know. (child)

Staff gave examples of the inappropriate use of the JJC for children from care backgrounds. This highlighted the lack of stability experienced by children and inadequate support for their mental health needs:

He was in and out of the [children's home] consistently ... He's in for nuisance offences... He has serious learning difficulties and there's a concern that this may lead to serious harm. (care staff)

I think the number of young people getting in from the care side is frightening. Some are disturbed, some are clearly suffering from mental illnesses, psychological problems ... You could be in a house where you're taken out of it for your own safety and put in a children's home and the first thing you know, you're locked up here. (care staff)

The report also highlighted issues regarding the use of force and physical restraint. Children were brought to the JJC either by the police or a private security firm and it was common for children to be handcuffed during escort. On admission, children were subject to a rub-down (airport style) search and although this did not involve the removal of clothing, the enforced intimacy could prove upsetting for children, many of whom have experienced physical and emotional abuse in their families and communities:

I hate other men touching my body. I hate people touching my body. I hate anyone touching my body. I don't like people touching my body at all . . . they touch you there [points to top of legs] search you and you feel like hitting them. (boy) 
The NIHRC's initial research in $2002^{83}$ expressed serious concern about high levels of physical restraint. Subsequent staff training in therapeutic crisis intervention (TCI) was instrumental in having significantly reduced its use: during the 18 months preceding fieldwork, the highest recorded number of restraints in one month was 30, the lowest four. Restraint involved staff "holding" a child without bringing her/him to the ground. Officially this was not defined as a pain compliance technique but children confirmed that pain was caused. All children interviewed had either seen another child being restrained or had been restrained themselves:

See when I get out of hand like, it's their job to control me . . I've seen about ten [staff] on a kid about that size [indicates small child]. It hurts them ... if they hurt them, it makes them more mad. It really makes them out of control. (boy)

They're not allowed to put handcuffs on for a fact; they put handcuffs on me and then started ... they nearly broke my wrists. I had cuts and everything right there, they were pulling that hard... When I first saw someone else getting restrained, I felt like helping the other wee lad instead of helping staff. This wee lad, a wee small thing, not even five foot and these men about six foot, and he was just getting jumped over ... it looked like they nearly killed him. He couldn't breathe or nothing. He's going "I can't breathe, I can't breathe" and staff didn't listen to him. (boy)

Incidents of violence and threats of violence by children directed at staff were also documented in house records: "young person threatened to 'break staff's fucking jaw" (a member of staff was "kneed in the face" in this incident); "tried to head butt staff member"; "threatening to stab staff". Sometimes, crisis intervention techniques were used successfully: "young person lunged towards staff to strike, verbally aggressive but deescalated very quickly using TCI techniques". However, the researchers also witnessed threats to restrain and isolate a child for refusing to go to bed until he first got a drink of juice. Fortunately, the incident was resolved without the use of restraint.

The report raises the issue of the impact on young children of being detained in custody and separated from family and friends, highlighting problems about family and privacy rights, ${ }^{84}$ and also regarding children's right to be safe and cared for. ${ }^{85}$ Following reception, a member of staff assessed and settled children and they were permitted to telephone their families. Staff recognised that entering custody, especially for the first time was "an anxious time for children, all kids are scared" (staff member). Staff and other young people's welcoming attitude and the domestic feel of the units helped allay children's fears but the experience of being locked alone in their room at night provoked anxiety:

It was a bit scary because all I done was sat and stared at the ceiling until about two or three in the morning. (boy)

I think everyone should have TV . . .'cause when you're in your bedroom, in your room, you can think about things. You can think about strange things, so you can ... like hanging yourself or something. Thought about it a few times. (boy)

Children confirmed there was no restriction on the frequency of visits by their families but practicalities and the relative inaccessibility of the centre made visits difficult and infrequent for some families. Younger siblings often found visits boring and children suggested that activity-based visits would be more enjoyable. Some children found visits

83 Kilkelly et al., In Our Care, n. 2 above.

84 CRC Article 16(1) refers to children's rights to privacy, and Article 7 to their right to know and be cared for by their parents. ECHR Article 8 protects the right to private and family life.

85 CRC Article 19. 
upsetting: "Look out the window and see them leaving. It annoys you." Some even refused visits to avoid distress:

I don't really like visits. Just do without them. Seen my ma and dad once, but they leave and you don't. I don't like when you're sitting here and they go. You'd like to be going back out.

More positively, a support group has now been set up by YJA staff to offer support to parents in a community setting.

Girls are always a small minority in the centre and care staff expressed an awareness of girls' particular vulnerability:

It's difficult, stressful for girls ... girls need special programme time. Some young girls have very special needs. (staff)

Boys also commented on girls' distress:

Some of the wee girls do your head in ... All the wee girls in here cry . . . they just cry. Everything they do. One of the wee girls [is] doing my head in for nothing, just sitting and watching TV and won't stop crying. (boy)

The centre employed a full-time psychologist, yet the extent to which individual casework could be conducted was limited by the high level of remands and rapid turnover of children. It was considered inappropriate to begin individual casework on deep-seated problems when a child was likely to be in custody for a brief time or when their future was uncertain and issues pertaining to the legal case could not be explored for children on remand.

Children's rights standards require rehabilitation and resettlement to be a primary objective of custody yet staff and children were pessimistic regarding the potential for the programmes offered or the custodial experience in general to "reform" or "rehabilitate". Assessment, planning and rehabilitative work were difficult when children were sometimes in the centre only for short periods and, for children on remand, rehabilitative work directly related to alleged offending could not be carried out for fear of interfering with the presumption of innocence or prejudicing the child's legal case. Staff and children held a shared scepticism about the effectiveness of dedicated crime reduction programmes:

In my opinion they [programmes] haven't been very effective, but we're hoping to improve ... the boys are coming back. They're only out a week or a fortnight and they're back having stolen another car. So how do you judge? (staff)

We know it already [drug awareness] ... It's a waste of time. (child)

Ultimately, the pressures on children returning to the community were significant:

We're sending them back to 10 mates [friends] who all steal cars every night and take drugs every night. That peer pressure is massive. (staff)

Staff recognised the need to understand children's offending behaviour within the context of their overall needs:

We need to address offending behaviour, but we need to look at the bigger picture at the welfare of children, their right to be safe and cared for. (staff)

Discussing the problems he had faced in his young life, a boy provided evidence of the complex and multi-layered issues facing many children in custody, including the impact of bereavement, family breakdown, experience of paramilitaries and being placed in the looked-after care system. He described his grief and anger following his father's death, which he considered the root of his problems:

Fell out with most of my family. They didn't talk to me for a while. I felt like nobody wanted me. None of my friends would hardly talk to me because I was 
in the children's home ... I've just been like that from [when] my dad died. My dad died when I was $11 \ldots$. I just get this big thing of anger inside me and it's coming out bit by bit. A wee bit's coming out at a time, but if I get that worked up it's all going to come out at once.

She [the psychologist] asked me about my whole life and I don't really like talking about it because there's that much things has happened in my life, between watching my friends die. You know I've actually seen two of my friends die. And then watching one when he was getting knee-capped, getting shot, punishment beat and whatever. I don't like talking about it because I go nuts. But I've seen myself in anger [while being videotaped by friend]. I ran round my room, I lifted my wardrobe and I clean threw it at the walls, smashed it, head-butted my walls ... By the time I finished, my room was a bomb-site.

The most recent inspection report found that the centre at Woodlands is "well managed" and children "very well cared for". ${ }^{86}$ Inspectors concluded that healthcare was of a high standard, there was a "strong educational ethos" and good use of personal development plans. ${ }^{87}$ Ultimately, however, the inspectors noted a high level of "security and safety" commenting that "while Woodlands has a strong childcare ethos, it is fundamentally a custodial facility for children who are charged with criminal offences". 88 The inspectorates' main concerns focused on "high turn-over rate" of children and the overrepresentation of children in custody of children coming from residential care placements, ranging from $22-58$ per cent on any day. ${ }^{89}$ The inspectors commented that these children could be detained in custody for the most trivial offences. The most recent figures show that the number of children admitted to the JJC has risen by 34 per cent since the previous year, with 475 children entering the centre. ${ }^{90}$ This included a 67 per cent increase in PACE admissions. The YJA explains that much of this rise is due to 17-year-olds being detained in the JJC under PACE, where previously they would have been held in police stations. While this is preferable for those children involved, it also suggests a breach of the principle of custody as a last resort. The admission of a child for fine default last year is also notable and of concern. The NIHRC's findings regarding the over-use of custody and the movement between the care and justice systems was confirmed by a report in 2008 by the CJINI. Some of the children detained in Woodlands have committed serious and violent acts, however, inspectors concluded that "many of the children whom Inspectors met were neither serious nor persistent offenders" but were "troubled children" placed in custody out of "benign intent" of courts and police concerned for children's safety, rather than because of any seriousness in their offending behaviour. Such placements, they concluded "breach international safeguards, and inappropriate use of custody for children remains a more pronounced problem in Northern Ireland than elsewhere in the UK". 91

The most recent annual report also notes a further reduction in the use of physical restraint: 58 incidents over the 2009-2010 period. ${ }^{92}$ Closed-circuit television has recently been introduced in all common rooms in response to the recommendations of a national survey on physical restraint and, while this improves safety, it raises issues regarding children's right to privacy.

86 CJINI, Inspection of Woodlands, n. 58 above, pp. vii-viii.

87 Ibid.

88 Ibid. p. 3 .

89 Ibid. p. 5.

90 YJA, Annual Report 2009-2010 (Belfast: YJA 2010), p. 29.

91 CJINI, Inspection of Woodlands, n. 58 above, p. vii.

92 YJA, Annual Report, n. 90 above, p. 29. 
Concerns about the use of custody for children with mental health problems and learning disabilities and difficulties persist. The CJINI reported on a "snapshot" of children in the JJC on 30 November 2007. That day, 20 children had a diagnosed mental health disorder, 17 a history of self-harm, eight were on the child protection register and 14 had a statement of educational needs. ${ }^{93}$

Hydebank Wood, a category C (low security) establishment on the outskirts of Belfast is run by the Northern Ireland Prison Service and has a capacity to accommodate up to 306 children, young men and adult women prisoners. The placing of an adult women's unit within a male young offender institution has been condemned by the NIHRC and the inspectorates. Hydebank Wood is used for the imprisonment of boys and young men aged 17 or over at the time of conviction and serving a period of four years or fewer in custody. Children aged 16 years can also be imprisoned in Hydebank Wood under the Treatment of Offenders (Northern Ireland) Act 1968 for offences which would be punishable with imprisonment in the case of an adult aged 21 or over. ${ }^{94}$ Young men can stay at Hydebank Wood until the day before their 24th birthday, after which they will be transferred to a higher security adult prison. Boys as young as 15 years old may be imprisoned in Hydebank Wood if they are considered a danger to themselves or others. ${ }^{95}$

As a prison establishment, staffed by prison officers, the regime at Hydebank Wood YOC is very different to that in Woodlands and the imprisonment of children there alongside young adult men and adult women is contrary to Article $37 \mathrm{C}$ of the CRC. Willow House the "juvenile unit" in Hydebank Wood has a capacity for holding up to 19 boys under 18 and as young as 15 years. Although the prison authorities attempt to keep boys separate from the young men and adult women, mixing does occur, for example, during transportation to and from court and during visits. A thematic review by the CJINI found that there was "no routine provision for the treatment of mental health illness among the juveniles" and that judges told inspectors that they considered Hydebank Wood "less well equipped" to deal with mental health issues than the other prisons. ${ }^{96}$

The inspection report published in 2008 found that management at Hydebank Wood was:

struggling to deal adequately with the complex and competing tasks of managing a variety of remand and sentenced juveniles and adult young men, on a site that also contained a women's facility. ${ }^{97}$

Inspectors found "too little purposeful activity", inadequate opportunity to get fresh air or exercise, insufficient separation of children from young adults, routine use of stripsearching and over-reliance on separation and solitary confinement as a response to selfharm. One child had been held in isolation for several weeks as a punishment for a minor offence, and had been refused a visit from his mother. ${ }^{98}$ Young men were "overwhelmingly negative" about the complaints procedures. ${ }^{99}$ Overall, the "different and distinct" needs of children were not being met. ${ }^{100}$

93 CJINI, Not a Marginal Issue: Mental health and the criminal justice system in Northern Ireland (Belfast: CJINI 2010), p. 50 .

94 Ibid. Part 1, s. 5.

95 Criminal Justice (Children) (Northern Ireland) Order 1998, Part 6, s. 13(1)b.

96 CJINI, Not a Marginal Issue, n. 93 above, p. 36.

97 CJINI, Report of an Announced Inspection of Hydebank. Wood Young Offender Centre by HM Chief Inspector of Prisons and the Chief Inspector of Criminal Justice in Northern Ireland 5-9 November 2007 (Belfast: CJINI 2008), p. 5.

98 Ibid. p. 12.

99 CJINI, Report of an Announced Inspection, n. 97 above, p. 13.

100 Ibid. p. 35. 
Responding on behalf of non-governmental organisation Include Youth to the 2007-2008 Independent Monitoring Board (IMB) Annual Report on Hydebank Wood, young people in the YOC told of their frustrations at the nature of the regime. ${ }^{101}$ Educational and vocational opportunities were limited and some children and young people were locked up for long periods:

Some days you can be lucky to get out for breakfast. ${ }^{102}$

Boys like us get locked all the time because we've no job. ${ }^{103}$

Young people reported that although some staff were "sweet" (good) often relationships with staff were negative:

you can get made to feel really small by the screws, call you names and all. ${ }^{104}$

Some wind you up so you'll crack, so they can lock you in your room. ${ }^{105}$

The Annual Report of the IMB for 2008-2009 confirmed that Hydebank Wood continued to operate a punitive regime for young people, based on the regular and increasing use of solitary confinement, which was having a negative impact on young people's behaviour. ${ }^{106}$ The maximum period for which young people could be held in cellular confinement (solitary isolation) had increased from seven days to 14. Poor industrial relations between the prison authorities and the Prison Officers Association and an associated "withdrawal of good will' led to greater lock-down of prisoners, including children, and prisoners found themselves "passive pawns" in the industrial dispute. ${ }^{107}$ The reason given for the lock-downs was "staff shortages" and yet the IMB noted that the prison appeared well staffed. The IMB also reported on the "significant weakness" of education and vocational training for boys and young men. 108 Worryingly, there were "no manifestations of the cultural change that was supposed to take place in Northern Ireland's prisons". There had been a "marginal" improvement in the way staff related to young people, but, in general, staff tended to "keep their distance" rather than engaging with prisoners. ${ }^{109}$ Seventy per cent of prisoners at Hydebank had mental illness and/or personality disorder and three out of four prisoners had difficulty reading and writing. ${ }^{110}$ The IMB found that there was no age-appropriate regime for children in Willow House. ${ }^{111}$

\section{Conclusion}

John Muncie argues that, despite the limitations of rights discourses, it is "equally important to appreciate their continuing potential. In this respect the CRC and related international directives ... provide a strong basis for rethinking juvenile justice."112 International human rights standards provide a useful benchmark against which we can measure the state's

101 Include Youth, Young People's Response to the Independent Monitoring Board Annual Report Hydebank Wood YOC and Prison 2007-2008 (Belfast: Include Youth 2010).

102 Ibid. p. 3.

103 Ibid. p. 4.

104 Ibid. p. 5.

105 Ibid. p. 6.

106 IMB, Hydebank. Wood Prison and Young Offenders Centre: Independent Monitoring Board's Annual Report for 2008-2009 (Belfast: IMB 2009), p. 4.

107 Ibid. p. 5.

108 Ibid.

109 Ibid.

110 Ibid. p. 6.

111 Ibid. p. 21.

112 J Muncie, “The United Nations, children's rights and juvenile justice” in W Taylor, R Earle and R Hester (eds), Youth Justice Handbook: Theory, policy and practice (Cullompton: Willan 2010), p. 11. 
response to children in custody. Speaking at an international conference on Kids Behind Bars, Professor Jaap E Doek, former chair of the CRC, criticised the inadequate response of many states to the protection of detained children, and stressed that meeting international obligations would not only promote the health and well-being of children in conflict with the law, it would also make a positive impact on youth-offending rates. ${ }^{113}$ As Thomas Hammarberg, Council of the Europe Commissioner for Human Rights comments, we know that "depriving children of their liberty tends to increase the rate of re-offending". ${ }^{114}$ Children's reconviction rates in Northern Ireland are 72.9 per cent for custody, 49.6 per cent for probation order and 44.3 per cent for court-ordered restorative conferences. ${ }^{115}$ Although more serious cases may be more likely to result in a custodial rather than community disposition, the reconviction rates are nonetheless an indictment of the effectiveness of child custody in preventing offending and re-offending.

During the life of the $\mathrm{CRC}$, there have been positive developments regarding protection of the rights of children in custody in Northern Ireland. Girl children are no longer held in adult prisons; the regime in Woodlands is better in terms of rights compliance than the punitive regime which pertained in Lisnevin. There is much that still needs to be done to ensure full compliance with the CRC. Rights breaches identified in the youth justice system in Northern Ireland include the low age of criminal responsibility at 10 years and the failure to incorporate the best-interests principle within youth justice legislation. Custody for children is used not only as a last resort or for the shortest appropriate period of time, with an over-use of remand in custody and delays in the system resulting in children spending longer on remand than is necessary. Recent research by Sinead Freeman and Mairead Seymour on the use of remand custody for young people in Ireland documents the potential damage caused by lengthy remand: "The uncertainty that characterizes the remand experience of these vulnerable young people serves to exacerbate their existing difficulties." The effects included "high levels of anxiety", "withdrawal from social contact with others" and "feelings of apathy and hopelessness". 116

The continued practice of imprisoning boys as young as 15 with young adults in Hydebank Wood YOC is a serious breach of Article 37C, yet, in evidence to a parliamentary committee at Westminster, Baroness Morgan confirmed that government is "content that arrangements for 17 year old boys [in Hydebank Wood] provide sufficient separation from the young adult males accommodated on the same site to meet Article 37 obligations". ${ }^{117}$ The state's response in Northern Ireland to the withdrawal of the UK's reservation to Article 37C has been to establish a working group of civil servants and youth justice and prison officials tasked with reducing numbers of children in Hydebank Wood, a wholly inadequate strategy which will leave some of the most distressed and vulnerable children in a prison setting. The regime at Hydebank Wood has been documented in research and inspection reports as punitive and inappropriate for children and young people.

113 J E Doek, CRC chair, "The CRC and kids behind bars", opening statement at the international conference: Kids behind Bars - A child rights perspective, Bethlehem: DCI Palestine 30 June-2 July 2005.

114 T Hammarberg, Viewpoint, n. 11 above.

$115 \mathrm{Mr}$ Andrew MacQuarrie, YJA, giving evidence to the Committee for Health Social Services and Public Safety at Stormont, 18 February 2010, Hansard.

116 S Freeman and M Seymour, "Just waiting: the nature and effect of uncertainty on young people on remand custody in Ireland" (2010) 10(2) Youth Justice 126-42, p. 138.

117 Baroness Morgan in House of Lords/House of Commons, Joint Parliamentary Committee on Human Rights, Children's Rights: Government response to the committee's 25th report of session 2008-2009, 10th report of session 2009-2010, HL Paper 65/HC 400, p. 17. 
One young person involved with Include Youth's response to the IMB report spoke of feelings that 'it's because we're nobody's, because they don't care about us on the outside, we're nothing, we don't matter". ${ }^{118}$ Children in custody do matter, and do have rights. The inclusion of provision within the Hillsborough Agreement for a review of children and criminal justice provides an opportunity to show to children and young people in conflict with society that as a society we do care and that as rights-holders they will be respected and protected. 